\title{
The effect of deferred grazing in spring and early summer pastures on pasture growth rate and feed quality
}

\section{B.P. DEVANTIER ${ }^{1}$, D.R. STEVENS ${ }^{2}$, G.M. RENNIE ${ }^{3}$ and K.N. TOZER
${ }^{3}$ AgResearch, Grasslands Research Centre, Private Bag 11008 Palmerston North, New Zealand ${ }^{2}$ AgResearch, Invermay Research Centre, Private Bag 50034 Mosgiel, New Zealand. ${ }^{3}$ AgResearch, Ruakura Research Centre, Private Bag 3123 Hamilton, New Zealand}

brian.devantier@agresearch.co.nz

\section{Abstract}

Maintaining pasture quality in late spring and early summer is a challenge in many hill country farming systems where pasture growth often exceeds animal demand. One possible management tool is to defer grazing on a portion of the farm to enable the desired grazing mangement and animal performance on the remainder. This study aimed to evalute the eflect of timing and distion of defered gazing in mid timing and ders quent pasture accumulation rates, composition and quality, from mid-spring through to the following winter. A factorial design (3 durations x 3 closing times) in eight replicates compared withholding grazing (nil, 1 or 3 grazings), in three closing periods, mid spring, late spring, and early summer. Grazing pasture when covers reached 2500 $3000 \mathrm{~kg} \mathrm{DM} / \mathrm{ha}$ to a residual of $1500 \mathrm{~kg} \mathrm{DM} / \mathrm{ha}$ was the standard grazing regimen used. Grazing after the exclusion period aimed to achieve the same residual as in the control treatment based on a feed budget. Short early closures resulted in little, or no change in pasture quality and quantity for the remainder of the season. Longer closure periods reduced pasture quality due to increases in the proportions of dead and reproductive stem. This effect was reduced with later closings. The control (nil deferred grazings) and mid-spring closings had a net loss of dead matter (-1000 and $-420 \mathrm{~kg} \mathrm{DM} /$ ha, respectively), while the late -spring and earlysummer closings accumulated 60 and $180 \mathrm{~kg} \mathrm{DM} / \mathrm{ha}$, respectively. These differences in dead matter were the major driver of the differences of net herbage accumulations $(\mathrm{P}=0.018)$, with net accumulations from $7990 \mathrm{~kg} \mathrm{DM} / \mathrm{ha}$ for the control (Nil) closings to 9660 $\mathrm{kg} \mathrm{DM} / \mathrm{ha}$ for the December (late) closings. Deferred grazing can be used to alter feed availability and utilisation while maintaining net pasture production over spring, summer and autumn.

Keywords: grazing management, pasture quality, deferred grazing, net pasture accumulation, dead matter, reproductive tillers, metabolisable energy

Introduction

The conversion of flat and rolling land to more intensive farming enterprises such as dairying and dairy upport, has reduced the area available for specialist sheep and beef finishing operations. This has resulted in increasing pressure on hill country farms, previously focused on breeding, to finish a higher proportion of stock. Profitable livestock finishing in hill country will require higher quality pasture than traditionally found in New Zealand hill country.

Typically, in most farming operations this presents pasture management challenges from mid-spring to early/mid-summer, when pasture growth rates are likely to exceed animal requirements. If the exces of pasture growth over animal requirements is not controlled or manipulated, the consequence is likely to be pastures of increasing mass, with a higher proportion of reproductive tillers and senescent material, with a subsequent loss in pasture quality (Sheath et al. 1984; Sheath et al. 1987).

On flat to easy country, land managers have the option of closing off a portion of the farm from grazing. This enables them to conserve surplus feed by producing hay or silage and match the feed grown on the remaining farm area to animal requirements. However, on most hill country farms there is an insufficient proportion of suitable land for this to be a viable option. Unless the farmer is able to acquire extra stock during periods grow vailable for managing the pasture and intensity of animal grazing.

Various spring and summer grazing managemen guidelines have been developed to inform hill country farmers of the influence of good pasture management on pasture quality and pasture accumulation (Smith \& Dawson 1977; Sheath \& Bircham 1983; Sheath et al. 1987).

Some of these have promoted the use of short periods of deferred grazing in mid-spring to early-summer to increase animal demand and keep control of pasture on the remainder of the farm. In practice this control is often not achieved.

To determine the costs and benefits of maintaining control of some areas at the expense of others (beyon the scope of this paper), it is necessary to determine the effect of the timing and duration of deferred grazing on 


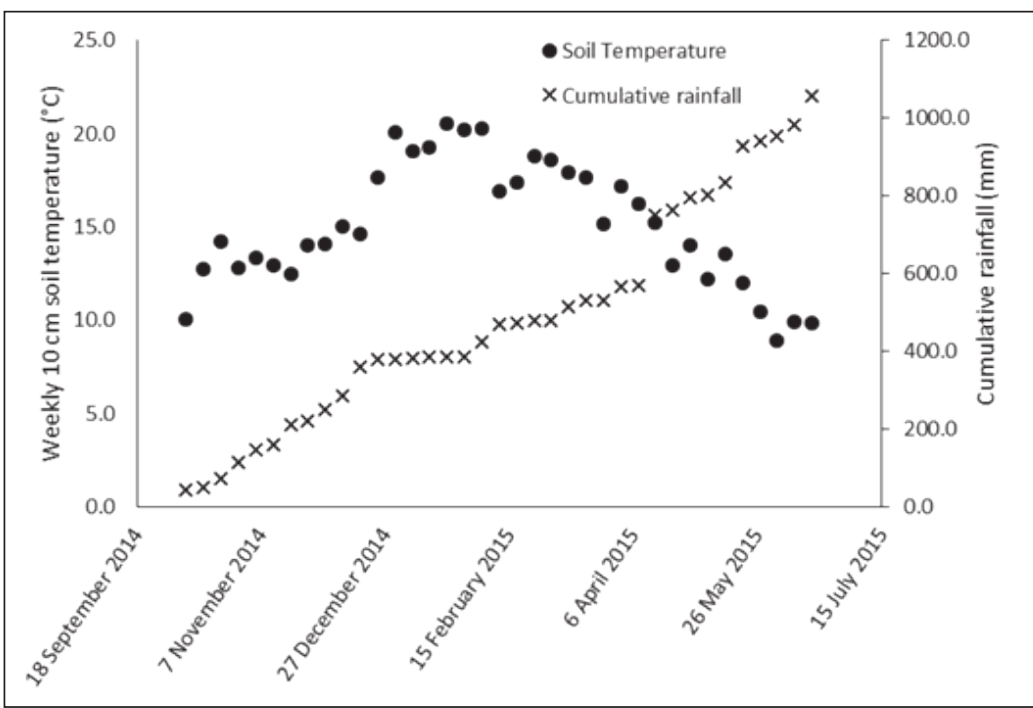

Figure 1 Weekly mean soil temperature and accumulative rainfall for the trial sites over the study period.

hill country pastures. Previous work in New Zealand sheep pastures has focused on the effects of deferred grazing on tiller dynamics (Matthew et al. 1991; Hernandez-Garay et al. 1993; Nie et al. 1997), although there has been some work on the impact of deferred grazing over a longer period (September to April/May) on pasture growth (e.g. Mackay et al. 1991).

Deferred grazing has been used in dryland Australian pastures to increase the perennial grass content of the pasture, decrease annual grass content and contro broadleaf weeds such as thistles (Burton \& Dowling, 2004; Nie et al. 2015). The impact of the deferral depends on the closing time and also on the starting botanical composition of the pasture. Burton \& Dowling (2004) recommend a threshold of $20 \%$ perennial cover for deferred grazing to increase the content of desirable perennial species and reduce the content of weeds. If the content of perennial species is lower than this, annual weedy species may produce seed and result in a greater abundance of weeds in the pasture through seedling recruitment. For example, reduced spring grazing pressure on ripgut brome grass (Bromus diandrus) dominant high country pastures in New Zealand, was related to increased ripgut brome seed production, with implications for carcass contamination of sheep (Tozer et al. 2007).

This study was designed within the context of providing New Zealand farm managers with option to manage the feed supply and better maintain pasture quality across their whole farm. In contrast to the above studies, using deferred grazing as a tool to manipulate the botanical composition was not the focus. The focus of this trial was to evaluate the effect of timing and duration of deferred grazing in mid-spring to early-summer on pasture accumulation rates and pasture quality from midspring through to the following winter.

\section{Materials and methods}

\section{Field location}

The study was conducted at the AgResearch Ballantrae Hill Country Research Station, Southern Hawke's Bay, New Zealand (408180S, 1758500E). Ballantrae is typical of much of the North Island's steep, pastoral hill country covering 3.5 million ha (28\% of the total area of farmland in New Zealand), and is located 125 to $350 \mathrm{~m}$ a.s.l. with an average air temperature of $12.8^{\circ} \mathrm{C}$ and annual rainfall of 1270 $\mathrm{mm}$, distributed evenly throughout the year. Data from weather stations located at the site of each replicate were pooled, and the mean soil temperature and rainfall are represented in Figure 1.

Brown and Pallic Soils (Hewitt 1998) are present i.e. yellow-brown earths and intergrades to yellow-grey earths and related steepland soils, mainly formed from tertiary sandstone, siltstone and mudstone, but with some loess influence.

The pasture growth pattern on the research station is typical of summer moist hill country, with $38 \%$ occurring in spring, $33 \%$ in summer, $17 \%$ in autumn and $12 \%$ in winter (Lambert et al. 1983) The conventional management of sheep on this class of farm reflets the challenge of matching animal demand to pasture growth with, typically, a mean lambing date of mid- to late-September, with weaning occurring from early- to late-December

\section{Trial structure and treatments}

A factorial design compared two deferred grazing treatments (miss one or miss three grazings), at three closing times, mid-spring (8 November), late-spring (28 November), and early-summer (17 December) (Table 1) to a control which was grazed at 3 to 4 week intervals throughout. Eight replicates were located on areas of low slope $\left(<15^{\circ}\right)$ but stratified across three areas of different soil fertility; low (2 replicates, average Olsen $P$ of 8 ), medium (2 replicates, average Olsen P of 30 ) and high (4 replicates, average Olsen $P$ of 56).

\section{Treatments:}

Control - no closure; graze at 3 - 4 week intervals provided pre-grazing pasture cover reached at least $2500 \mathrm{~kg} \mathrm{DM} / \mathrm{ha}$

Mid-spring Short closure 1

(miss 1 grazing at $1^{\text {st }}$ rotation)

Mid-spring Long closure 3 -

(miss 3 grazings starting from $1^{\text {st }}$ rotation)

Late-spring 1 - Short closure

(miss 1 grazing from $2^{\text {nd }}$ rotation)

Late-spring 3 - Long closure

(miss 3 grazings starting from $2^{\text {nd }}$ rotation)

Early-summer 1- Short closure

(miss 1 grazing from $3^{\text {rd }}$ rotation)

Early-summer 3 - Long closure

(miss 3 grazing's starting from $3^{\text {rd }}$ rotation)

All plots (each $10 \times 10 \mathrm{~m}$ ), except those from which grazing was withheld, were grazed whenever the average pasture mass of the control plots had reached 2000-3000 kg DM/ha. Grazing management aimed $2000-3000 \mathrm{~kg} \mathrm{DM} / \mathrm{ha}$. Grazing management aimed
to achieve a residual of $1500 \mathrm{~kg} \mathrm{DM} / \mathrm{ha}$ in 48 hours. An allowance of $1 \mathrm{~kg} \mathrm{DM} / \mathrm{sheep} /$ day was at each grazing event. If there was insufficient pasture available to require 48 hour grazing by the minimum number of animals, grazing periods were shortened. After the exclusion period, grazing aimed to achieve the same residual as standard grazing events, based on the same allowance.

\section{Measurements and analysis}

Pasture measurements were conducted from immediately before the first grazing in mid-spring until after the final grazing in mid-June of the following winter.

Total pasture mass was estimated by rising plate meter (RPM) calibrated specifically at each grazing date for replicate at both pre- and post-grazing events to achieve a residual of $1500 \mathrm{~kg} \mathrm{DM} / \mathrm{ha}$ in 48 hours.
An allowance of $1 \mathrm{~kg} \mathrm{DM} / \mathrm{sheep} /$ day was used, with

as described in Devantier (1998). When delayed grazing resulted in lodged pasture, or a pasture height greater than the height capacity of the RPM, pasture mass $(\mathrm{kg} \mathrm{DM} / \mathrm{ha})$ was estimated from three randomly positioned $0.4 \mathrm{~m}^{2}$ quadrats cut to ground level in each plot, with subsamples $(200 \mathrm{~g})$ oven dried (24 hours, $80^{\circ} \mathrm{C}$ temperature)

Pre-grazing pasture composition and quality was estimated from randomly clipped pasture samples (5 (1) . The sample was chilled mmediately and separated into 2 subsamples. One subsample was separated into grass leaf, grass stem, clover, weed, dead stem, and other dead material. Components were oven-dried for 24 hours at $60^{\circ} \mathrm{C}$ and weighed to estimate their contribution to total DM. The second subsample was used to estimate feed quality (metabolisable energy ME, and crude protei CP) which was assessed using near inf ared reflectan spectroscopy (NIRS) (Corson et al. 1999), undertaken at a commercial laboratory. Post-grazing, subsamples were separated into live and dead fractions only.

For both pre- and post-grazing pasture dissections, dead matter was defined as completely dead $(100 \%$ brown). In the event of a mixture of dead, senescing (yellow brown but still with moisture) and green in a single piece of plant material, the dead material was separated and colo

Pasture mass accumulated for each rotation was calculated as the difference between post-grazing pasture mass at the end of one grazing and pre-grazing pasture mass for the following grazing. A feature of using this approach is that dead material decay can occur and result in a net loss of dead material. Total metabolisable energy (ME) was calculated as the energy density in pre-grazed pasture multiplied by the mass of pata were analysed comparing

Table 1 Trial treatments; time and length of closure (withheld from grazing).

\begin{tabular}{|c|c|c|c|c|c|c|c|c|c|}
\hline $\begin{array}{l}\text { Closed from } \\
\text { grazing }\end{array}$ & $\begin{array}{l}\text { Withholding } \\
\text { grazing periods }\end{array}$ & $\begin{array}{l}\text { Mid-spring } \\
\left(19^{\text {th }} \text { Oct }\right)\end{array}$ & $\begin{array}{l}\text { Mid-spring } \\
\left.\text { Early Nov ( } 8^{\text {th }}\right)\end{array}$ & $\begin{array}{l}\text { Late-spring } \\
\text { Late Nov }\left(28^{\text {th }}\right)\end{array}$ & $\begin{array}{l}\text { Early-summer } \\
\text { Dec }\left(17^{\text {th }}\right)\end{array}$ & $\begin{array}{l}\text { Jan } \\
\left(10^{\text {th }}\right)\end{array}$ & $\begin{array}{l}\text { Feb } \\
\left(3^{\text {rd }}\right)\end{array}$ & $\begin{array}{l}\text { Feb/Mar } \\
\left(28^{\text {th }} \mathrm{Feb}\right)\end{array}$ & $\begin{array}{l}\text { Final grazing } \\
\text { June }\left(21^{15 t}\right)\end{array}$ \\
\hline Control & Nil & & & & & & & & \\
\hline Mid-spring 1 & 1 & & & & & & & & \\
\hline Mid-spring 3 & 3 & & & & & & & & \\
\hline Late-spring 1 & 1 & & & & & & & & \\
\hline Late-spring 3 & 3 & & & & & . & & & \\
\hline Early-summer & er 1 & & & & & & & & \\
\hline Early-summer & er 3 & & & & & & & & \\
\hline
\end{tabular}

Grazed $\quad$ Not Grazed

(Mean dates of grazings) 
as the fixed effects and replication as the random effect using the REML function of GenStat (1 $7^{\text {th }}$ Edition).

\section{Results}

\section{Total pasture accumulated}

There were no significant interactions $(\mathrm{P}>0.05)$, but for completeness, the data for all treatment combination are presented

Effect of length of closure

The accumulation of green pasture (Table 2) was significantly affected by length of closure $(\mathrm{P}<0.01)$ being lowest in the long closure $(8130 \mathrm{~kg} \mathrm{DM} / \mathrm{ha})$, intermediate in the control $(8990 \mathrm{~kg} \mathrm{DM} / \mathrm{ha})$ and highes in the short closure $(9420 \mathrm{~kg} \mathrm{DM} / \mathrm{ha})$. In contrast, there was a significantly greater accumulation of dead matter in the long closure $(630 \mathrm{~kg} \mathrm{DM} / \mathrm{ha}, \mathrm{P}<0.001)$, while in the short closure and control there was a net loss of dead matter (averaging $875 \mathrm{~kg} \mathrm{DM} / \mathrm{ha}$ ).

Effect of closing date

Closing date significantly affected total and dead pasture accumulation (Table 2). There was a net loss of dead material in the control and in pastures closed in mid-

spring of 1000 and $420 \mathrm{~kg}$ dead DM/ha, respectively, but there was an accumulation of dead matter (60 and $180 \mathrm{~kg} \mathrm{DM} / \mathrm{ha}$, respectively) when pastures were closed in late-spring and early-summer. These differences in dead matter $(\mathrm{P}<0.001)$ were the major driver of the differences in net pasture accumulation $(\mathrm{P}=0.018)$, with net accumulation ranging from $7990 \mathrm{~kg} \mathrm{DM} / \mathrm{ha}$ for the control (Nil closings) to $9660 \mathrm{~kg}$ DM/ha for earlypasture accumulation was detected.

\section{Feed quality}

Effect of the length of closure

The ME and CP concentration were higher in vegetation sampled in the control and short closure than the long closure (10.7 and 10.1 MJ ME/kg DM, 192 and 172 g CP/kg DM, respectively, $\mathrm{P}<0.001)$. However, there was no effect of length of closure on total metabolisable energy (GJ ME/ha) accumulated over the study period (Table 2)

\section{Effect of closing time}

Metabolisable energy accumulated over the study period (Table 2) was lowest in the control (84.7 GJ

Table 2 Accumulation of total, green and dead pasture mass, and energy content over late spring, summer and autumn when grazing was withheld in the short and long closure treatments, from either Mid-spring. Late-spring or Early-summer.

\begin{tabular}{|c|c|c|c|c|c|c|c|}
\hline & Closing Time & Control & Short closure & Long closure & Mean & $P$ value & LSD $_{5 \%}$ \\
\hline \multirow[t]{5}{*}{ Total (kg DM/ha) } & Control & 7990 & & & $7990 \mathrm{~b}$ & & \\
\hline & Mid-spring & & 8114 & 8186 & $8150 \mathrm{~b}$ & & \\
\hline & Late-spring & & 8137 & 8545 & $8340 \mathrm{~b}$ & & \\
\hline & Early-Summer & & 9752 & 9562 & $9660 \mathrm{a}$ & 0.018 & 1132 \\
\hline & Mean & 7990 & 8670 & 8760 & & 0.835 & 997 \\
\hline \multirow[t]{5}{*}{ Green (kg DM/ha) } & Control & 8990 & & & & & \\
\hline & Mid-spring & & 9013 & 8128 & 8570 & & \\
\hline & Late-spring & & 8968 & 7589 & 8280 & & \\
\hline & Early-summer & & 10265 & 8683 & 9470 & 0.126 & 1045 \\
\hline & Mean & $8990 \mathrm{ab}$ & $9420 \mathrm{a}$ & $8130 \mathrm{~b}$ & & 0.004 & 920 \\
\hline \multirow[t]{5}{*}{ Dead (kg DM/ha) } & Control & -1000 & & & $-1000 c$ & & \\
\hline & Mid-spring & & -899 & 59 & $-420 \mathrm{~b}$ & & \\
\hline & Late-spring & & -831 & 955 & $60 \mathrm{ab}$ & & \\
\hline & Early-summer & & -512 & 878 & $180 \mathrm{a}$ & $<0.001$ & 520 \\
\hline & Mean & $-1000 \mathrm{~b}$ & $-750 \mathrm{~b}$ & $630 \mathrm{a}$ & & $<0.001$ & 460 \\
\hline \multirow[t]{5}{*}{ Total energy (GJME/ha) } & Control & 84.7 & & & $84.7 \mathrm{~b}$ & & \\
\hline & Mid-spring & & 86.7 & 95.3 & $91.0 \mathrm{ab}$ & & \\
\hline & Late-spring & & 86.2 & 88.5 & $87.4 \mathrm{~b}$ & & \\
\hline & Early-summer & & 103.0 & 97.6 & $100.3 \mathrm{a}$ & 0.046 & 11.4 \\
\hline & Mean & 84.7 & 92.0 & 93.8 & & 0.696 & 10.1 \\
\hline
\end{tabular}

Subscripts are for comparisons within the column or within the row for 'Mean' data for each of Total, Green, Dead and Total energy
$\mathrm{ME} / \mathrm{ha}$ ), intermediate in the mid-spring and late-spring closing $(91.0$ and $87.4 \mathrm{GJ}$ $\mathrm{ME} / \mathrm{ha}$, respectively) and highest in the early-summer closing (100.3 GJ ME/ ha, $\mathrm{P}<0.05)$. The effect of closing time on the energy and protein concentration in the accumulated pasture was similar for all three closing times, which were all lower than the control treatment $(\mathrm{P}=0.046)$. The energy content of the three closing times ranged from 10.2 to $10.3 \mathrm{MJ} \mathrm{ME} / \mathrm{kg}$ DM whereas the energy content of the control was higher at $10.7 \mathrm{MJ} \mathrm{ME} / \mathrm{kg}$ $\mathrm{DM}(\mathrm{P}<0.001)$. A similar pattern occurred with the protein content of the three closings times ranging from 179 to $180 \mathrm{~g} \mathrm{CP} / \mathrm{kg}$ DM, which were all lower than the control (193 g CP/ kg DM, $\mathrm{P}<0.01)$.

Some aspects of the variation in potential feed on offer compared to control

Total pasture mass

Figure 2 represents the potential amount of pasture on offer for the various closing time and durations chosen. The total pasture accumulated during a closure period was greate for the short closure than the control ranging from

1700 to $2500 \mathrm{~kg} \mathrm{DM} / \mathrm{ha}$, depending on the closing date. After the closure period, pasture on offer was greater in the short closure than in the control $(400-1000 \mathrm{~kg}$ DM/ha)

Pasture accumulation initially increased during the closure period in the long closure, after which the accumulation then depended on the closing date. Immediately after the closure period, pasture on offer was also greater in the long closure than in the control (1600-2900 kg DM/ha).

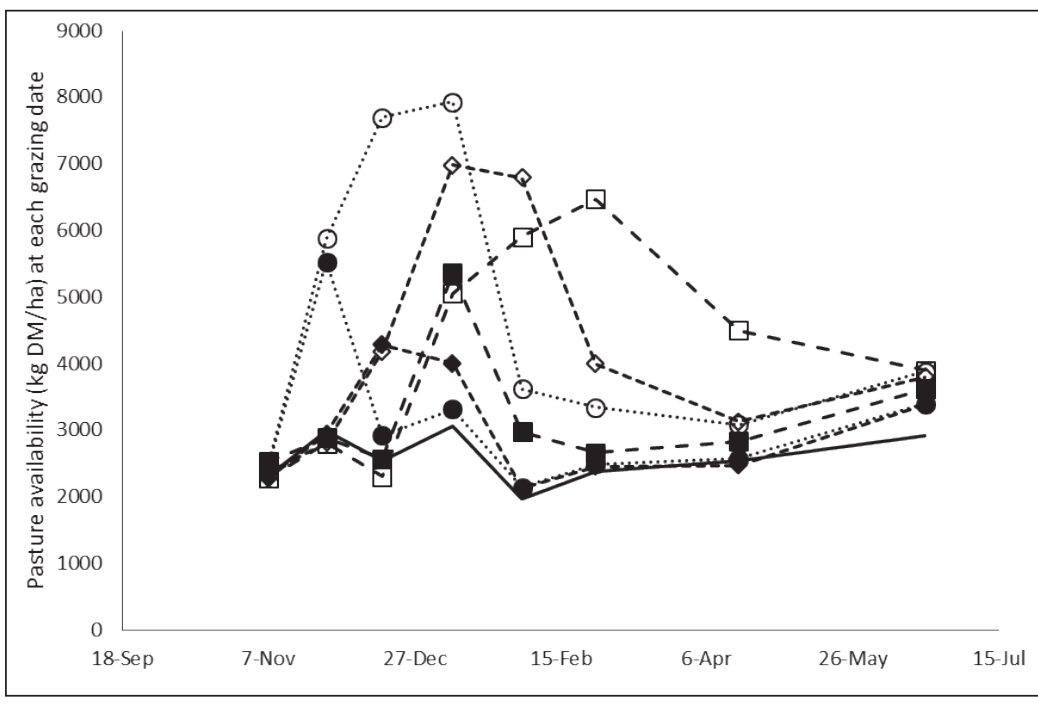

Figure 2 Pasture availability (feed-on-offer) in deferred grazing treatments (Control: solid line;

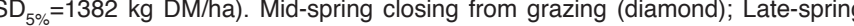

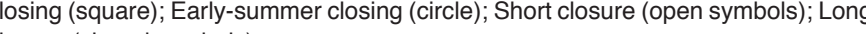
closure (closed symbols)

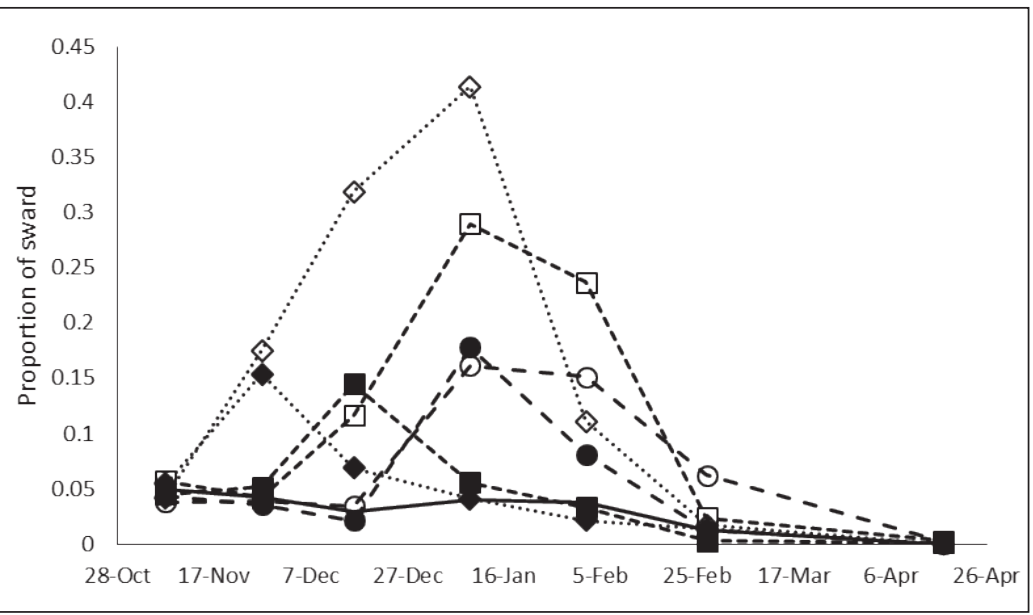
treatments compared with the control (Control: solid line; $\mathrm{LSD}_{5 \%}=0.041$ ). Mid(dare); Early-summer closing spring Closing (dlamond), Lare-spring closing (square);
Pasture composition

Of note were the changes in dead material and seedhead were no si so they are not reported.

Reproductive stem

Figure 3 depicts the difference in reproductive stem development in the deferred treatments in comparison to the control. Closure date had no effect on the peak abundance or seasonal distribution of reproductive 


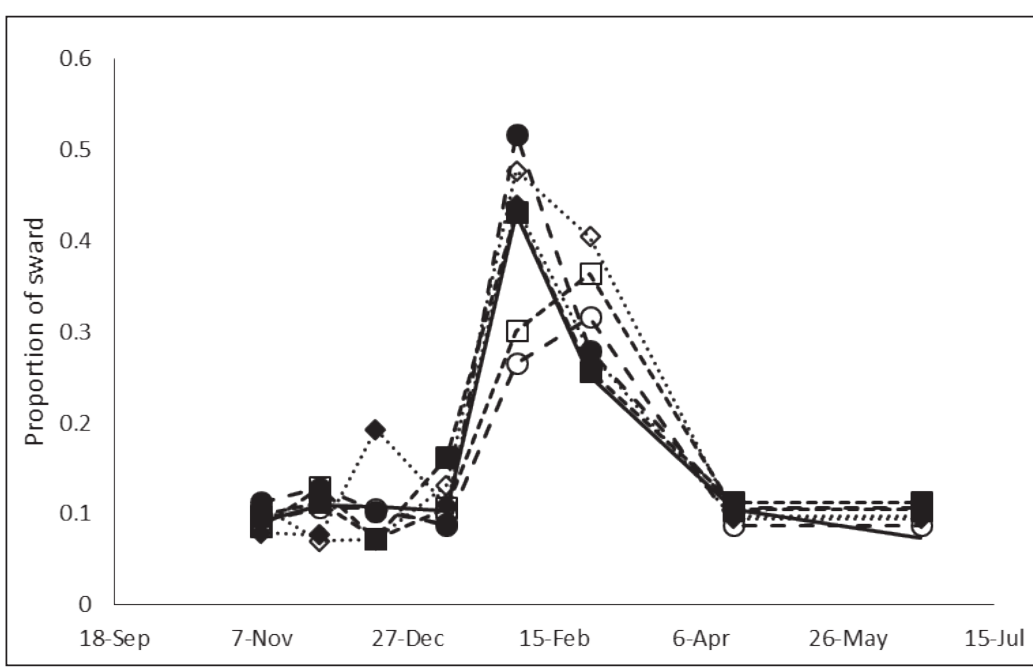

Figure 4 Contribution of dead material as a proportion of total sward dry matter of the deferred and control treatments (Control: solid line, $\mathrm{LSD}_{5 \%}=0.045$ ). Mid-spring Short closure (open symbols); Long closure (closed symbols). here. These factors include soil carbon, organic nitrogen levels and soil physical properties, root biomass, grass tiller densities, clover stolon growth, establishment success of natural reseeding, and providing a suitable environment for the introduction of im the introduction of

Withording a pacies.

Withholding a paddock from grazing changes seasonal herbage production, and also affects pasture quality by altering the botanical composition as discussed above (Burton \& Dowling 2004, Nie et al. 1997) and accie al. 1997) and accumulation of living and dead plant material. Often livestock

stem in the short closure, whereas there were distinct differences between the closing dates in the long closure. The earliest closing date in mid-spring had the greatest difference from the control; the effect of this was evident in the first grazing after the closure period. In comparison, there was a smaller difference between late-spring and early-summer closing dates and the control in the proportion of reproductive stem, and there were no differences between these three treatments once grazing had resumed. Differences in seedhead accumulation before grazing had a carryover effect on pasture composition after the return to grazing, with more dead seedhead present with earlier closings.

\section{Dead matter}

Short closures (Figure 4) showed a similar pattern of increased dead leaf in the first growth period after the return to grazing with this returning to the same levels as the control by the second grazing after the closure period. In contrast, in the long closures, early closure increased the accumulation of dead leaf within the sward with each grazing until late-summer, while there was less dead leaf in the two later closing date treatments in mid-summer, followed by raised levels in the late-summer. There was no difference betw of the treatments and the control plots by mid-autumn.

\section{Discussion}

The data presented in this paper focuses on the influence of deferring grazing on pasture production an availability. Other effects such as consequences on the effects of pastoral fallow on the sward and soil (Mackay et al. 1991; Nie et al. 1997) are not considered seedling recruitment, tillering and content of existing perennial plants and clovers, resulting in an improve pasture botanical composition and quality in the following seasons (Nie et al. 1996; Nie \& Zollinger 2012; Nie et al. 2015).

However, early spring closing times can negatively influence feed supply at a critical time for animal performance if this occurs before pasture accumulation exceeds demand. When specifically targeting a developing feed surplus, withelling grazing on a on one area can help to better match feed supply and demand across the whole farm.

Restoring pasture condition from the lower quality, higher pasture mass under deferred grazing may compromise livestock performance in the short term (Sheath et al. 1987; Waghorn et al. 2007). However, this needs to be considered against the benefits of matching feed supply and demand, and maintaining pasture quality on the remainder of the farm. To achieve this, hill land managers will require an understanding of when pasture surpluses develop, and be able to monitor feed supply and demand. This will ensure animal production is optimised and enable priority control of pasture in areas where, once lost, pasture quality will not fully recover until the following winter (Sheath $e t$ al. 1984; Sheath et al. 1987).

\section{Conclusions}

Withholding grazing on a portion of the farm in mid spring to early summer may be a viable management option for controlling or manipulating feed quantity and quality on the remainder of the farm. The length and timing of the closure affects both the quantity and quality of pasture grown between mid-spring and the start of the following winter. Early closures of short duration $(<6$ weeks) are likely to result in no or slight increases in net pasture accumulation with minimal loss of feed quality once standard grazing residuals are reinstated. As the length of the deferred grazing is increased, the total pasture accumulated will increase. However, this will be at the expense of pasture quality, although later closings reduce the decline. The option of early and short through to longer and later closures from grazing, allows flexibility when hill land managers develop strategies for managing season specific pasture surpluses. This information will be critical to determine the benefits and practicality of grazing strategies to control late-spring and early-summer pasture quality in New Zealand summer moist hill country.

\section{ACKNOWLEDGEMENTS}

The authors would like to acknowledge Ministry of Business, Innovation and Employment, DairyNZ, Fonterra, Beef + Lamb New Zealand and DCANZ for funding through the P21 partnership programme.
The authors would also like to acknowledge the AgResearch Farm Systems and Farm field teams for technical support, in particular S. Brock and Y. Gray for their skill and diligence in botanical analysis.

\section{REFERENCES}

Burton, J.; Dowling, P. 2004. Pasture management for weed control: a grazier's guide to controlling annual weeds in southern Australian improved pastures. Orange, New South Wales, Australia, NSW Agriculture and the Co-operative Research Centre for Australian Weed Management. 56 pp.

Corson, D.C.; Waghorn, G.C.; Ulyatt, M.J.; Lee, . 1999. NIRS: Forage analysis and livestock feeding. Proceedings of the New Zealand Grassland Association 61: 127-132.

Devantier, B.P. 1998. Comparison of three methods of measuring herbage production in continuously sheep prom Polytechnic, New Zealand.

Sernandez-Garay, A.; Hodgson, J.; Matthew. C. 1993. Spring grazing management and tiller dynamics in ryegrass/white clover pasture. Proceedings of the New Zealand Grassland Association 55: 133-136.

Hewitt, A.E. 1998. New Zealand soil classification, 2nd Ed. Landcare Research Science Series 1.

Lambert, M.G.; Clark, D.A.; Grant, D.A.; Costal. D.A.; Fletcher, R.H. 1983. Influence of fertiliser and grazing management on North Island moist hill country 1. Herbage accumulation. New Zealand Journal of Agricultural Research 26: 95-108.

Mackay, A.D.; Budding, P.J.; Ross, D.J.; Tate, K.R.; Orchard, V.A.; Hart, P.B.S.; Kettles, H.A. 199 Pastoral fallow for improving low fertility hill country pastures. Proceedings of the New Zealand Grassland Association 53: 209-233.

Matthew. C.; Chu. A.C.P.; Hodgson, J.; Mackay. A.D. 1991. Early summer pasture control: what suits the plant Proceedings of the New Zealand Grassland Association 55: 133-136.

Nie, Z.N.; Valentine, I.; Mackay, A.D.; Barker, D.J. Hodgson, J. 1996. Long-term effects of pastora fallowing on the distribution and performance of white clover (Trifolium repens L.) in a hill country pasture. Grassland Research and Practice Series 6: 75-78.

Nie, Z.N.; Mackay, A.D.; Barker, D.J.; Valentine, I; Hodgson, J. 1997. Changes in plant population density, composition and sward structure of a hill pasture during pastoral fallow. Grass and Forage Science 52: 190-198.

Nie, Z.N.; Zollinger, R.P. 2012. Impact of deferred grazing and fertilizer on plant population density, ground cover and soil moisture of native pastures in steep hill country of southern Australia. Grass and Forage Science 67: 231-242. 
Nie, Z.N.; Zollinger, R.P.; Behrendt, R. 2015. Impact of deferred grazing and fertilizer on herbage production, soil seed reserve and nutritive value of native pasture in steep hill country of southern Australia. Grass and Forage Science 70: 394-405.

Sheath, G.W.; Bircham, J.S. 1983. Grazing management in hill country: pasture production. pp. 41-45. In Proceedings of the Ruakura Farmers' Conference. Hamilton.

Sheath, G.W.; Hay, R.J.M.; Giles, K.H. 1987. Managing pastures for grazing animals. pp. 6574. In: Livestock feeding on pasture. Ed. Nicol, A.M. New Zealand Society of Animal Production, Hamilton.

Sheath, G.W.; Webby, R.W.; Pengelly, W.J. 1984 Management of late spring-early summer pasture surpluses in hill country. Proceedings of the New Zealand Grasslands Association 45: 199-206.

Smith, M.E.; Dawson, A.D. 1977. Hill country grazing management. Proceedings of the New Zealand Grassland Association 38: 47-55.

Tozer, K.N.; Marshall,A.J.; Sedcole, J.R.; Edwards, G.R. 2007. Ripgut brome (Bromus diandrus) distribution in relation to topography and management on seven high country properties in the South Island. New Zealand Plant Protection 60: 168-173.

Waghorn, G.C.; Burke, J.L.; Kolver, E.S. 2007. Principals of feeding value. Managing pastures for grazing animals. pp. 35-59. In: Pastures and supplements for grazing animals. Ed. Rattray, P.V.; Brookes, I.M.; Nicol, A. M. New Zealand Society of Animal Production, Hamilton.

\section{Estimation of ergovaline intake of cows from grazed perennial ryegrass containing NEA2 or standard endophyte}

C.C. EADY ${ }^{1}$, J.R. CORKRAN ${ }^{1}$, K.M. BAILEY ${ }^{1}$, G.A. KERR ${ }^{1}$ and A.M. NICOL ${ }^{2}$ ${ }^{1}$ Agriseeds Ltd, 2547 Old West Coast Road RD1, Christchurch, 7671, New Zealand ${ }^{2} A M N$ Consulting, 1248 Old West Coast Road, RD 1, Christchurch 7671, New Zealand

$$
\text { ceady@agriseeds.co.nz }
$$

\section{Abstract}

Ergovaline concentration was measured monthly from December 2015 to April 2016 in herbage of perennial ryegrass pastures containing NEA2 or standard endophyte (SE) in the Waikato, Manawatu and Canterbury. Ergovaline concentrations were then combined with estimated pasture intake, pasture botanical composition and cow liveweight data from experimental dairy farm systems in the Waikato and Canterbury to estimate dairy cow ergovaline intake (mg/kg LW ${ }^{0.75} /$ day). For the diploid ryegrass 'Trojan' with NEA2 estimated ergovaline intake ranged from 0.01 to $0.029 \mathrm{mg} / \mathrm{kg} \mathrm{LW} \mathrm{LW}^{0.75} / \mathrm{day}$, levels at which no significant animal production effects have been reported. Ergovaline intake of tetraploid ryegrass 'Bealey NEA2' was at least an order of magnitude lower than this. For the diploid ryegrass, 'Bronsyn' with SE, ergovaline intake was 0.016 to $0.056 \mathrm{mg} / \mathrm{kg}$ $\mathrm{LW}^{0.75}$ /day, which at the highest level carried a $\sim 20 \%$ risk of causing animal production effects for $15 \%$ of the samples. AR1 and AR37 pastures, used as controls, contained nil or trace amounts of ergovaline.

Keywords: alkaloid, Epichloë festucae var. lolii, Lolium

\section{Introduction}

The perennial ryegrass endophyte Epichloë festucae var lolii provides the plant protection against insect attack by producing alkaloids, mainly lolitrem B, peramine, ergovaline and epoxy-janthitrems (Popay \& Hume 2011). These compounds, apart from peramine, can be associated with detrimental effects on animals at particular levels of intake. Lolitrem B is a neuro-toxin associated with the neuromuscular disorder 'ryegrass staggers' in grazing animals (di Menna et al. 2012). Some strains of Epichloë festucae var. lolii endophyte including AR1 (Fletcher 1999a), AR37 (Hunt \& Newman 2005) and NEA2 (Tian et al. 2013) produce little or no lolitrem B and are commercially marketed in perennial ryegrass as offering insect protection with reduced likelihood of animal health and production issues.

NEA2 and AR37 produce the alkaloids ergovaline and epoxy-janthitrems, respectively, that can have detrimental animal affects above certain intake levels. Epoxy-janthitrems are tremorgenic compounds (Finch et al. 2012) and AR37 is marketed with the caveat that it can cause ryegrass staggers (https://www.agricom. co.nz/rd/endophyte-information/ar37).

Ergovaline plays a role in producing physiological effects in animals similar to those of fescue toxicosis, with a review by Klotz \& Nicol (2016) concluding the

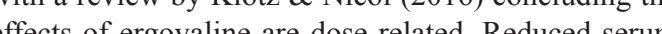
serum esed respiration rate have been reported at low ergovaline intake (0.02$0.04 \mathrm{mg} / \mathrm{kg} \mathrm{LW} 0.75 / \mathrm{day})$, increased core temperature at moderate intake $\left(0.04-0.06 \mathrm{mg} / \mathrm{kg} \mathrm{LW}{ }^{0.75} /\right.$ day $)$, and economically important symptoms of reduced DM intake, milk production or liveweight gain usually associated with ergovaline intake above $0.07 \mathrm{mg} / \mathrm{kg}$ $\mathrm{LW}^{0.75} /$ day. The review concluded that "quantitative data on the ergovaline profiles of novel endophytes in both the grazed and residual portions of the pasture are needed".

This study aimed to measure ergovaline concentration in the grazed component of several perennial ryegrass cultivars containing novel or SE, including the diploid commercially sold as 'Trojan NEA2' and the tetraploid cultivar sold as 'Bealey NEA2'. Ryegrass stubble, below a simulated grazing height $(4-5 \mathrm{~cm})$, could not be tested in this study as the National Forage Variety Variety Trial (NFVT) protocol stipulates that grass plots canno be cut to ground level.

When NEA2 was released it was believed to be single endophyte strain, but subsequent genotyping showed it is a mix of several endophytes. 'Trojan NEA2', as sold and used in this study, contains two biochemically distinct endophytes (NEA2 and NEA6, both protected by Plant Variety Rights) and each representing approximately $50 \%$ of the endophyte content (breeding lines a testedbefore ' markers, NEA6 in 'Trojan' has been shown to be two separate endophyte strains (Fletcher et al. 2017), however, alkaloid analysis has shown that their profiles are similar (unpublished data). 'Bealey NEA2', as sold, contains two endophytes, approximately $85 \%$ of strain NEA2 and 15\% NEA6.

Three locations within the two New Zealand mega- 